\title{
In Vitro Cell Death Discrimination and Screening Method by Simple and Cost- Effective Viability Analysis
}

\author{
Katharina Helm ${ }^{\mathrm{a}, \mathrm{b}}$ Marlena Beyreis ${ }^{\mathrm{a}, \mathrm{b}} \quad$ Christian Mayr ${ }^{\mathrm{a}, \mathrm{c}} \quad$ Markus Ritter ${ }^{\mathrm{a}, \mathrm{b}, \mathrm{d}}$ \\ Martin Jakab ${ }^{\mathrm{b}}$ Tobias Kiesslich ${ }^{\mathrm{a}, \mathrm{c}}$ Kristjan Plaetzer
}

aLaboratory for Tumour Biology and Experimental Therapies, Institute for Physiology and Pathophysiology, Paracelsus Medical University, Salzburg, 'Laboratory for Functional and Molecular Membrane Physiology, Institute for Physiology and Pathophysiology, Paracelsus Medical University, Salzburg, 'Department of Internal Medicine I, Paracelsus Medical University / Salzburger Landeskliniken, Salzburg, 'Department for Radon Therapy Research, Ludwig Boltzmann Cluster for Arthritis and Rehabilitation, Salzburg, 'Laboratory of Photodynamic Inactivation of Microorganisms, Department of Cell Biology and Physiology, University of Salzburg, Salzburg, Austria

\section{Key Words}

Viability analysis • Apoptosis • Necrosis • Cell death • Cytotoxicity

\begin{abstract}
Background/Aims: For in vitro cytotoxicity testing, discrimination of apoptosis and necrosis represents valuable information. Viability analysis performed at two different time points post treatment could serve such a purpose because the dynamics of metabolic activity of apoptotic and necrotic cells is different, i.e. a more rapid decline of cellular metabolism during necrosis whereas cellular metabolism is maintained during the entire execution phase of apoptosis. This study describes a straightforward approach to distinguish apoptosis and necrosis. Methods: A431 human epidermoid carcinoma cells were treated with different concentrations / doses of actinomycin D (Act-D), 4,5,6,7-tetrabromo-2-azabenzimidazole (TBB), Ro 31-8220, $\mathrm{H}_{2} \mathrm{O}_{2}$ and photodynamic treatment (PDT). The resazurin viability signal was recorded at 2 and 24 hrs post treatment. Apoptosis and necrosis were verified by measuring caspase 3/7 and membrane integrity. Results: Calculation of the difference curve between the 2 and 24 hrs resazurin signals yields the following information: a positive difference signal indicates apoptosis (i.e. high metabolic activity at early time points and low signal at 24 hrs post treatment) while an early reduction of the viability signal indicates necrosis. For all treatments, this dose-dependent sequence of cellular responses could be confirmed by independent assays. Conclusion: Simple and cost-effective viability analysis provides reliable information about the dose ranges of a cytotoxic agent where apoptosis or necrosis occurs. This may serve as a starting point for further in-depth characterisation of cytotoxic treatments.
\end{abstract}




\section{Introduction}

Cell death has been characterised to occur in several different forms depending on the cell type and stimulus studied [1-3]. However, in many circumstances and regarding morphology, the most important types of cell demise are apoptosis (programmed / active cell death) and necrosis (passive cell death).

Apoptosis is a strictly regulated physiological energy-consuming process essential for normal development, elimination of degenerated cells, metabolism, cell turnover, as well as functioning and development of the immune system $[4,5]$. It is characterised by cell shrinkage, pyknosis, karyorrhexis and eventual phagocytosis of the dying cell $[1,3,4,6]$. Contrary to this, necrosis leads to cytoplasmatic swelling, a dehiscence of the plasma membrane and subsequent release of intracellular material into the extracellular environment, causing inflammatory responses in the surrounding tissue $[4,6]$. Both cell death mechanisms can occur simultaneously in different subpopulations of cells and - in most cases - are dependent on the applied concentration or dose of a cytotoxic agent as well as the cell type [4].

Quantification of cell death and identification of the cell death modes is an important information for general physiological questions and drug development including in vitro studies on cytotoxicity in different cell types as well as the dose- and time- dependency of the cytotoxic action [7]. Most assays that are currently used for detection and discrimination of apoptosis and necrosis are based on measurement of cellular characteristics: mitochondrial membrane potential decrease and cytochrome c release [8], caspase activation [9-11], morphological changes (cell swelling or shrinkage, membrane blebbing) [12-14], nuclear fragmentation [15, 16], DNA cleavage i.e. 'DNA laddering' [17], membrane integrity [11], release of intracellular compounds [18] and phosphatidylserine (PS) exposure [19]. Complementing these approaches, several types of cell viability assays exist for estimation of overall viability or viable cell mass that measure different surrogate parameters such as reducing potential and metabolic activity (e.g. resazurin, AlamarBlue ${ }^{\circledR}$, CellTiter-Blue $^{\circledR}[7,11,20,21]$ ), enzyme activity (conversion of tetrazolium salts such as MTT, MTS, WST [22, 23]) and adenosine triphosphate (ATP) levels [11, 24, 25]. The resazurin assay is based on the reduction of the oxidised, non-fluorescent, blue state (resazurin) to the fluorescent, pink state (resorufin) by components of the mitochondrial electron transport chain and mitochondrial and cytoplasmatic enzymes of viable and metabolically active cells (see [26-28] for details). A decreased rate of reduction (resazurin conversion) therefore indicates impairment of cellular metabolism [27].

Based on the fact that apoptosis is an energy-requiring, controlled and active process which takes several hours (depending on the cell type and probably the apoptosis inducer) to be completed, we have previously used an in vitro assay system based on viability analysis to simultaneously detect and discriminate apoptosis, necrosis and survival responses after photodynamic treatment (PDT) $[25,29,30]$. This approach is based on the observation that during PDT-induced apoptosis, cells maintain constantly high ATP levels until late in the apoptotic process to ensure sufficient energy supply for the energy-dependent steps in the apoptotic cascade [29-31]. As this requires active cellular metabolism, these metabolic dynamics during apoptosis - contrasting necrosis with a fast or immediate ATP and plasma membrane integrity breakdown - can be employed in viability assays if performed at two time points following treatment: at an early time point (e.g. 2 hrs), necrotic cells have already lost their metabolic activity whereas apoptotic cells are still metabolically active. At a later time point (e.g. $24 \mathrm{hrs}$ ), these cells have completed the apoptotic process and have undergone secondary necrosis (in vitro, in the absence of phagocytising cells) [32]. The difference curve calculated from early and late measurements can be interpreted to distinguish all three conventional cellular responses (survival at low, apoptosis at intermediate and necrosis at higher concentrations / doses), as discussed in the context of PDT-induced cytotoxicity in previous reports [25, 29-31].

To provide a definitive validation of this methodological approach, we tested the viability-based detection and discrimination using the resazurin assay for several different 
apoptosis inducers (4,5,6,7-tetrabromo-2-azabenzimidazole (TBB), Ro 31-8220, actinomycin-D (Act-D), $\mathrm{H}_{2} \mathrm{O}_{2}$, photodynamic treatment) in an in vitro model system (A431 human epidermoid carcinoma cells). Confirmed by independent assays for apoptosis and necrosis, the results obtained for dose-dependent analyses demonstrate that time-dependent viability analysis can reliably detect and discriminate cell survival / proliferation, apoptosis and necrosis. Provided that the test is performed in 96-well or even 384-well microplates to ensure comparability of all samples and includes a sufficient number of different drug doses or concentrations (dose-dependent cell response characteristics), the approach described in the present report represents a cost-efficient and simple method to gain first information on the dose / concentration-dependent type of cytotoxicity within an in vitro treatment.

\section{Materials and Methods}

Cell culture and treatment with apoptosis inducers

Human epidermoid carcinoma cells (A431, ATCC-Nr. CRL-1555) were cultured in Dulbecco's modified Eagle's Medium (DMEM) containing $4.5 \mathrm{~g} / \mathrm{l}$ glucose, $3.7 \mathrm{~g} / \mathrm{l} \mathrm{NaHCO}{ }_{3}$, stable glutamine (Biochrom, Berlin, Germany) and supplemented with 5\% foetal bovine serum (FBS) (FBS Superior, Biochrom), $1 \mathrm{mM}$ NaPyruvat (Sigma-Aldrich, Vienna, Austria), antibiotic antimycotic solution (100 U/ml penicillin, $0.1 \mathrm{mg} / \mathrm{ml}$ streptomycin, $0.25 \mu \mathrm{g} / \mathrm{ml}$ amphotericin-B; Sigma-Aldrich), in a humidified atmosphere at $37^{\circ} \mathrm{C}$ and $5 \%$ $\mathrm{CO}_{2}$. For measurement of cell viability, caspase 3/7 activity and membrane integrity, 10,000 cells per well were seeded into transparent 96-well microplates (Sarstedt, Nümbrecht, Germany). Prior to treatment (24 hrs after seeding the cells), cells were washed once with $100 \mu \mathrm{l} 0 \%$ FBS DMEM (further referred to as 'DMEM'). As established apoptosis inducers, the following drugs or treatments were used: RO 31-8220 (bisindoylmaleimidine IX, pan-PKC inhibitor, Selleckchem, Munich, Germany [33]), TBB (casein kinase II inhibitor, Sigma-Aldrich [34]), actinomycin D (DNA-dependent inhibitor of RNA synthesis, Abcam Biochemicals, Cambridge, United Kingdom [35]), $\mathrm{H}_{2} \mathrm{O}_{2}$ (Sigma-Aldrich [36]) and a PDT treatment (Foscan ${ }^{\circledR}$, BioLitec Pharma, Dublin, Ireland [37]). Cells were incubated with eleven different concentrations (serial 1+1 dilution) of RO 31-8220 (starting at $10 \mu \mathrm{M})$, TBB $(40 \mu \mathrm{M})$, Act-D $(20 \mu \mathrm{M})$, or $\mathrm{H}_{2} \mathrm{O}_{2}(40 \mathrm{mM})$ in DMEM. Based on previous experience $[25,29,30]$, the samples were incubated at $37^{\circ} \mathrm{C}$ for 2 or $24 \mathrm{hrs}$ for the resazurin viability analysis, $5 \mathrm{hrs}$ for caspase 3/7-activity [38] and 2 hrs for membrane integrity measurements, respectively. For PDT treatment, cells were incubated with $0.3 \mu \mathrm{M}$ of Foscan ${ }^{\circledR}$ in DMEM for 20 hrs, washed once with $100 \mu \mathrm{l}$ DMEM per well and illuminated with a $660 \mathrm{~nm}$ LED array [39] with energies ranging from 0.07 to $1.05 \mathrm{~J} / \mathrm{cm}^{2}$ (0.5-7.5 min illumination) and processed as described above. The final volume per well after treatment is $100 \mu \mathrm{l}$ for the cell viability assays, whereas in all other assays it is $50 \mu \mathrm{l}$ per well.

Time-dependent cell viability assay

The procedure for time-dependent viability analysis as well as the theoretical basis for interpretation is summarised in Fig. 1. After incubation for 2 or $24 \mathrm{hrs}$, cell viability was measured in each half of the 96well microplate using the resazurin assay (7-Hydroxy-3H-phenoxazin-3-one-10-oxide sodium salt; SigmaAldrich). The supernatant was replaced by $100 \mu \mathrm{l}$ DMEM containing $0.5 \mathrm{mM}$ resazurin (stock solution 2.5 $\mathrm{mM}$ in phosphate-buffered saline, PBS). After $1 \mathrm{hr}$ of incubation at $37^{\circ} \mathrm{C}, 90 \mu \mathrm{l}$ of the supernatant were transferred to a new 96 -well microplate and stored at $-20^{\circ} \mathrm{C}$ until measurement. The fluorescence of the product (resorufin) was detected at $\lambda_{\mathrm{ex}}=535 \mathrm{~nm}$ and $\lambda_{\mathrm{em}}=595 \mathrm{~nm}$ (intensity-top-measurement) using a Zenyth microplate reader (Anthos, Salzburg, Austria). Mean viability values were corrected for blank values (without cells) and related to untreated controls (UTC, without apoptosis inducer). All treatments were measured in quadruplicate wells, repeated three times and final results represent mean percentages of untreated controls \pm SEM.

Apoptosis assay - caspase $3 / 7$

Five hours post-treatment, caspase $3 / 7$ activity was measured by means of the Caspase-Glo ${ }^{\circledR} 3 / 7$ Assay based on the luminogenic peptide substrate DEVD (Promega, Mannheim, Germany) following the manufacturer's instructions. Cell treatments were performed using $50 \mu \mathrm{l}$ supernatant in single wells and after addition of the substrate $(50 \mu \mathrm{l} /$ well $)$ and $20 \mathrm{~min}$ of incubation at $37^{\circ} \mathrm{C}, 90 \mu \mathrm{l}$ of the supernatant were transferred to a white 96-well microplate (Greiner, Kremsmünster, Austria). The luminescence was measured with the Zenyth microplate reader (integration time: $1 \mathrm{~s}$ ). Results represent mean values \pm SEM of at least three independent experiments. 


\section{Necrosis assays}

Early loss of membrane integrity accompanied by release of intracellular material, i.e. necrosis, was verified using the CytoTox-ONE ${ }^{\mathrm{TM}}$ Homogeneous Membrane Integrity Assay (Promega), which is based on the amount of active lactate dehydrogenase (LDH) released into the supernatant by necrotic cells. According to the manufacturer's instructions, after $100 \mathrm{~min}$, the plate was transferred to room temperature $\left(22^{\circ} \mathrm{C}\right)$ and after additional $20 \mathrm{~min}$ (i.e. at $2 \mathrm{hrs}$ post-treatment), $50 \mu \mathrm{l}$ of the CytoTox-ONE ${ }^{\mathrm{TM}}$ reagent were added to all wells. After incubation for $10 \mathrm{~min}$ at room temperature, $25 \mu \mathrm{l}$ of stop solution were added to all wells and the fluorescence signal was measured with an Infinite M200 microplate reader (Tecan, Grödig, Austria). All samples were related to maximum LDH release values (positive control) and were measured in single wells. Results represent mean values \pm SEM of four independent experiments. Positive control wells (maximum LDH release values) were generated by addition of Triton X100 (final concentration 1\% v/v; Scharlau, Scharlab, Spain) $10 \mathrm{~min}$ prior to addition of the CytoTox-ONE ${ }^{\mathrm{TM}}$ reagent and subsequently processed as described above.

As the CytoTox-ONE ${ }^{\mathrm{TM}}$ Assay did not give reliable LDH-release signal after PDT treatment in preliminary experiments, for PDT samples, necrosis was measured using the CytoTox-Glo ${ }^{\mathrm{TM}}$ Cytotoxicity Assay (Promega). This assay uses a luminogenic peptide substrate (AAF-Glo ${ }^{\mathrm{TM}}$ Substrate) to measure specific protease activity, which is only detectable after membrane integrity loss. For this purpose, 2 hrs post treatment, $25 \mu \mathrm{l}$ of CytoTox-Glo ${ }^{\mathrm{TM}}$ reagent were added to each well, accompanied by positive control wells (Triton X100, as described above). After 15 min of incubation at room temperature, the luminescence signal was measured using the protocol described above for the CytoTox-ONE ${ }^{\mathrm{TM}}$ Assay.

\section{Results}

Time-dependent viability analysis

Figure 2A shows the results from the resazurin-based viability analysis obtained at the two time points ( 2 and 24 hrs) post

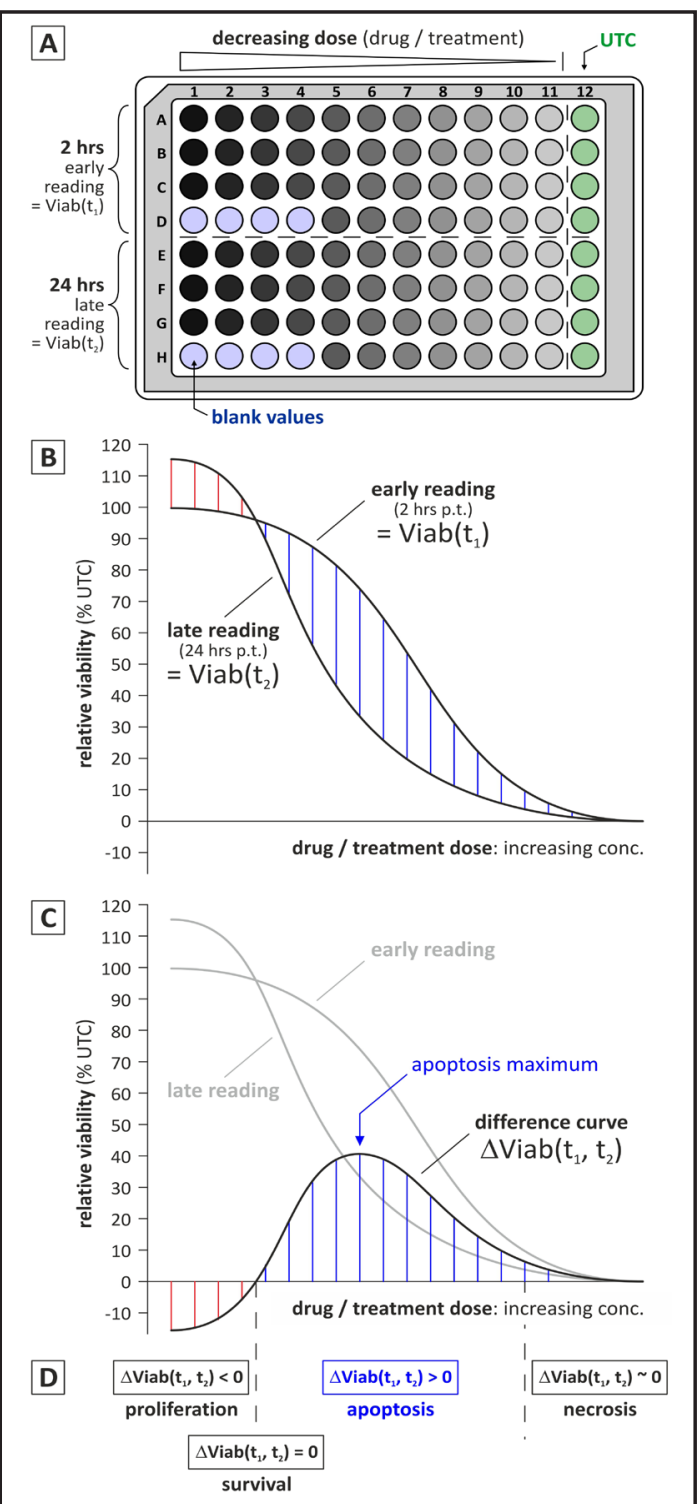

Fig. 1. Plate layout and experimental workflow of the time-dependent viability analysis. (A) Plate layout for 2 measurement time points, 11 different drug doses, blanks and untreated control wells. (B) Raw data for early and late viability measurement. (C) Calculation of the early versus late reading difference curve. (D) Interpretation relating to the drug / treatment dose ranges. Abbreviations: UTC, untreated control; Viab, viability. Modified from [25].

treatment: for Ro 31-8220, $\mathrm{H}_{2} \mathrm{O}_{2}$ and PDT (row a, d, e), a concentration-dependent continuous decrease of the $2 \mathrm{hrs}$ viability signal can be noted (e.g. down to $<10 \%$ of untreated controls at $\mathrm{H}_{2} \mathrm{O}_{2}$ concentrations $>10 \mathrm{mM}$ ) while for TBB and Act-D (row b and c), the early reading (2 $\mathrm{hrs}$ ) indicates no or only small decreases of viability even at the highest drug concentrations. In contrast, viability measured at $24 \mathrm{hrs}$ post treatment drops to nearly $0 \%$ for all treatments - either at the highest concentration (Ro 31-8220, TBB) or already at lower concentrations (Act-D, $\mathrm{H}_{2} \mathrm{O}_{2}$, PDT). 


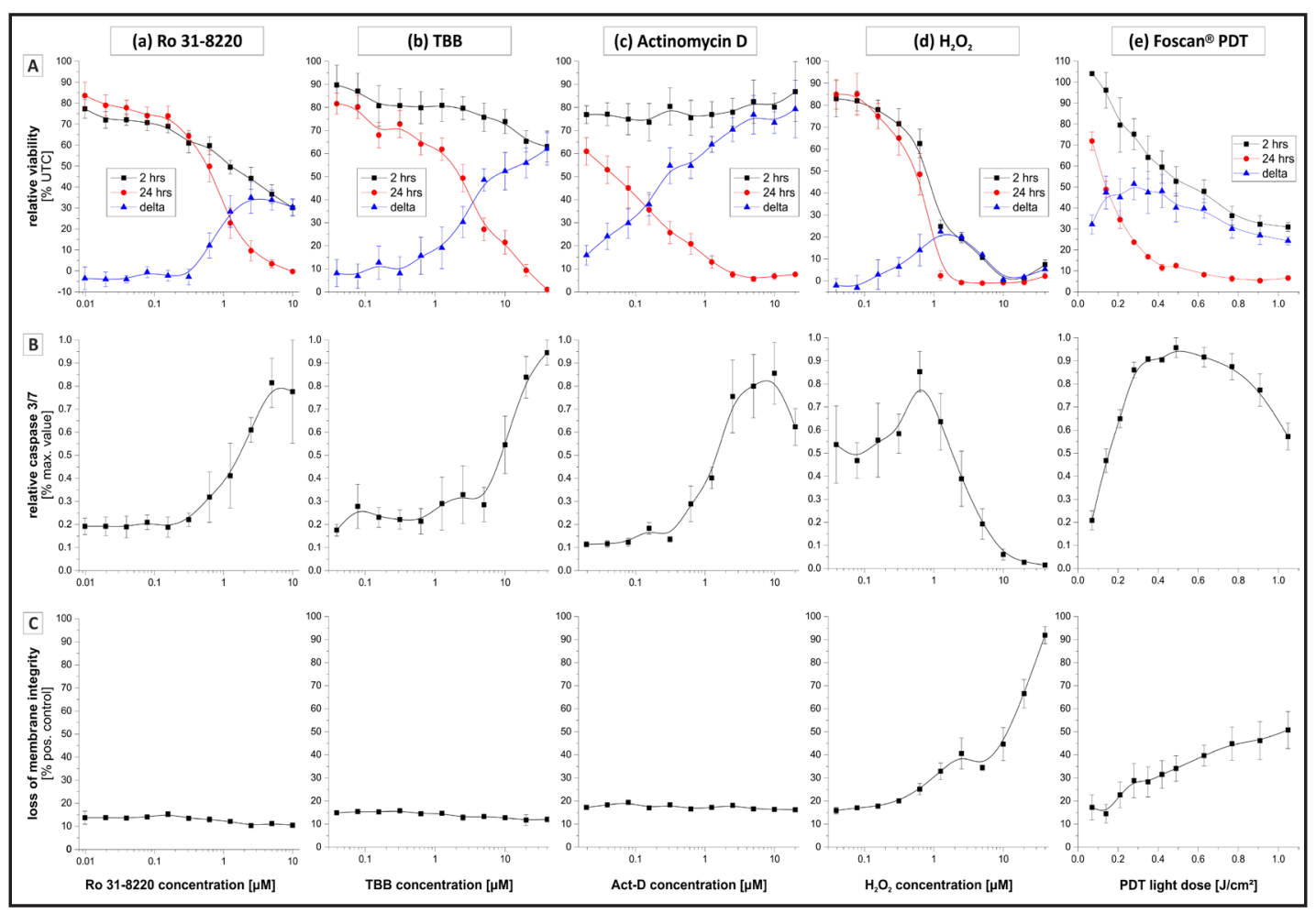

Fig. 2. Establishment and validation of viability-based cell death discrimination. For several cytotoxic agents including Ro 31-8220, TBB, Act-D, $\mathrm{H}_{2} \mathrm{O}_{2}$ and photodynamic treatment (PDT), the proposed viability-assay and specific tests for apoptosis and necrosis were performed for a range of concentrations / doses. (A) Cell viability values measured with resazurin assays at 2 (filled squares) and 24 hrs (filled circles) post treatment and related to the signal of untreated controls (UTC, 100\%). Filled triangles represent the difference curve calculated by subtraction of the late from the early viability reading. (B) Caspase $\mathrm{Glo}^{\circledR} 3 / 7$ activity at 5 hrs post treatment. (C) Necrosis measured by LDH release (CytoTox-ONE ${ }^{\mathrm{TM}}$ ) indicating loss of membrane integrity for Ro 31-8220, TBB, Act-D and $\mathrm{H}_{2} \mathrm{O}_{2}$. For PDT treatments, necrosis was measured based on the detection of dead cell protease-release with AAF-Glo ${ }^{\mathrm{TM}}$ Substrate (CytoTox-Glo ${ }^{\mathrm{TM}}$ ).

Interpretation and identification of cell death modes

As outlined in Fig. 1, the peak of the curve calculated by subtraction of the late from the early viability reading should indicate the range of concentrations (treatment doses) where cells undergo apoptosis. The 'delta' curves in Fig. 2A show distinct peaks for $\mathrm{H}_{2} \mathrm{O}_{2}$ and PDT treatment, while for Ro 31-8220, TBB and Act-D the difference curve continuously increases with increasing drug concentrations. In case of $\mathrm{H}_{2} \mathrm{O}_{2}$ and PDT, higher concentrations or treatment doses beyond the peak of the difference curve result in its decrease back down to $\sim 0 \%$. This is due to the small (absent) viability difference between early and late viability readings at these (highest) concentrations indicating treatment doses where all cells lose their viability early after treatment. As described in Fig. 1, this dynamics can be interpreted as necrotic cell death characterised by early loss of membrane integrity and metabolic activity.

\section{Verification of apoptosis}

Figure 2B shows the results for apoptosis induction (caspase $3 / 7$ activity) at 5 hrs post treatment (based on previous studies $[29,30]$ ) using the identical concentrations and treatment doses as for the viability analysis: the peak of caspase activity corresponds well with the peak of the viability difference curve ('delta') in case of Ro 31-8220, $\mathrm{H}_{2} \mathrm{O}_{2}$ and PDT treatment. For TBB and Act-D, only the left (raising) part of the caspase activation peak is observable - well reflecting the continuous increase of the viability difference curve up to the highest concentrations. Beyond the maximum of caspase activity, higher drug / treatment 
doses (in case of Ro 31-8220, Act-D, $\mathrm{H}_{2} \mathrm{O}_{2}$ and PDT) cause a decrease of the caspase signal within the concentration ranges that are presumably causing necrotic cell death.

Verification of necrosis

In figure 2C, results from the necrosis induction measurements are shown. Necrosis induction was measured by LDH activity or necrosis-specific release of cell proteases into the supernatant from leaky, i.e. necrotic cells. While for the 'biochemical' apoptosis inducers (Ro 31-8220, TBB and Act-D) no increase of necrosis can be observed at any concentration employed, high concentrations $(>5 \mathrm{mM})$ of $\mathrm{H}_{2} \mathrm{O}_{2}$ and PDT doses $\left(>0.2-0.4 \mathrm{~J} / \mathrm{cm}^{2}\right)$ cause a continuous increase of the LDH signal. This increase again corresponds well to the 'necrosis range' indicated by the viability difference analysis (Fig. 2A) which identifies the same treatment ranges as necrosis-inducing - based on the absence of a difference between early and late viability readings.

\section{Discussion}

Today, several distinct cell death mechanisms are described including anoikis, autophagic cell death, cornification, mitotic catastrophe, excitotoxicity, entosis, pyroptosis, netosis, oncosis and parthanatos [2,3] which question the 'formal' classification of cell death including only three variants: i) apoptosis (type I), ii) autophagy (type II, extensive cytoplasmatic vacuolization), and iii) necrosis (type III, showing neither apoptotic nor autophagic characteristics) [40]. However, the morphologically most distinct and experimentally most often observed death types are apoptosis and necrosis. The discrimination of cell survival, apoptosis and necrosis represents an important basic information for determining appropriate drug concentrations for many in vitro experiments and hence importantly also for drug development including characterization of a drug's cytotoxic, dose- and timedependent mode of action [7]. While qualitative and quantitative identification of apoptosis and necrosis is based on morphological and biochemical characteristics ascribed to these types of cell demise (see introduction), notably, these 'hallmarks' do not represent definitive and stand-alone criteria for discrimination of the cell death mode [40]. Examples include that mitochondrial cytochrome-c release was observed in cells undergoing necrosis [41], caspase inhibition could delay cell death after plasma membrane disruption [42], caspase-3 activation occurs under physiological conditions not related to cell death [43], apoptosis may occur without DNA cleavage while oncosis may involve such changes [44], PS exposure is involved in numerous (patho-)physiological processes (e.g. platelet activation and swellinginduced erythrocyte haemolysis [45-47]), and, canonical apoptotic stimuli may induce initial cell swelling $[48,49]$.

The aim of this study was to validate a rapid and cost-effective in vitro method that can serve as an easy-to-use tool to distinguish between apoptosis and necrosis - based on simple viability analyses. Viability assays represent a cost-effective method to distinguish living from dead cells based on metabolic activity (mostly as enzymatic activity / reducing potential). As the temporal kinetics of this activity is different for apoptotic and necrotic cells [25, 29-31], performing viability assays at an early and a late time-point after death induction gives information about when and at which doses cells undergo apoptosis and secondary necrosis. The late time point (e.g. at $24 \mathrm{hrs}$ post treatment) measures the viability present after completion of apoptosis and - in cell culture, i.e. in the absence of phagocytising cells secondary necrosis [31]. In contrast, an early viability signal can be attributed to cells either having survived the treatment or being in the process of apoptosis which requires active metabolism and energy supply until late steps in the apoptotic process [29, 30]. Positive values (peak) of the calculated difference between early and late measurements stand for the proportion of cells which have lost their viability compared to the early time point of measurement and, therefore, indicate the dose range where apoptosis has been triggered. Table 1 summarises viability assays based on metabolic activity which are suitable for the proposed time-dependent assay approach.

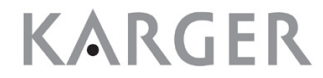


After cell death induction with TBB and Act-D, the difference curve is increasing continuously indicating a homogenous apoptotic population at the highest drug dose. Contrary to that, the difference curve after $\mathrm{H}_{2} \mathrm{O}_{2}$-treatment has a narrow peak: this well reflects the apoptotic population of cells as verified by the caspase assay and is followed by increasing loss of membrane integrity indicating necrotic cells. Reflecting the nature of PDT as a cytotoxic treatment which is based on (unspecific) generation of reactive oxygen species (ROS), the viability difference curve shows a rather broad peak - i.e.

a broad range of apoptosis induction in a subpopulation of cells and a dose-dependent continuous increase of a necrotic subfraction of cells.

While the interpretation of the viability reads in our experiments is confirmed by independent and specific assays for apoptotic and necrotic cell death, application of this approach for other cell types or treatment conditions may require establishment of particular assay conditions. Most importantly, the time points of the viability assay must be chosen to allow for correct interpretation: if a cell type requires more time to complete the apoptotic programme (e.g. $>24 \mathrm{hrs}$ ), the time point for 'late' measurement has to be adjusted accordingly. Furthermore, the results obtained by the proposed viability analyses should be confirmed by tests more specific for apoptosis / necrosis for each new cell type to ensure validity of the results.

\section{Conclusion}

Provided that appropriate measurement time points are known for a certain cell type and cytotoxic agent, simple and cost-effective cell death discrimination is possible by viability analysis and may serve as screening method for evaluation of new drugs or cytotoxic treatments.

\section{Disclosure Statement}

The authors declare no conflict of interest.

\section{References}

1 Galluzzi L, Aaronson SA, Abrams J, Alnemri ES, Andrews DW, Baehrecke EH, Bazan NG, Blagosklonny MV, Blomgren K, Borner C, Bredesen DE, Brenner C, Castedo M, Cidlowski JA, Ciechanover A, Cohen GM, De Laurenzi V, De Maria R, Deshmukh M, et al.: Guidelines for the use and interpretation of assays for monitoring cell death in higher eukaryotes. Cell Death Differ 2009;16:1093-1107.

2 Galluzzi L, Vitale I, Abrams JM, Alnemri ES, Baehrecke EH, Blagosklonny MV, Dawson TM, Dawson VL, El-Deiry WS, Fulda S, Gottlieb E, Green DR, Hengartner MO, Kepp O, Knight RA, Kumar S, Lipton SA, Lu X, Madeo F, Malorni W, Mehlen P, Nunez G, Peter ME, Piacentini M, Rubinsztein DC, Shi Y, Simon HU, Vandenabeele P, White E, Yuan J, Zhivotovsky B, Melino G, Kroemer G: Molecular definitions of cell death subroutines: recommendations of the Nomenclature Committee on Cell Death 2012. Cell Death Differ 2012;19:107-120. 


\section{Cellular Physiology Cell Physiol Biochem 2017;41:1011-1019 and Biochemistry Publisned \begin{tabular}{l|l} 
DOI: 10.1159/000460910 & $\begin{array}{l}\text { C } 2017 \text { The Author(s). Published by S. Karger AG, Basel } \\
\text { www.karger.com/cpb }\end{array}$
\end{tabular}}

Helm et al.: Cell Death Screening by Viability Analysis

3 Krysko DV, Vanden Berghe T, D'Herde K, Vandenabeele P: Apoptosis and necrosis: detection, discrimination and phagocytosis. Methods 2008;44:205-221.

$\checkmark 4$ Elmore S: Apoptosis: a review of programmed cell death. Toxicol Pathol 2007;35:495-516.

5 Porter AG, Janicke RU: Emerging roles of caspase-3 in apoptosis. Cell Death Differ 1999;6:99-104.

-6 Taatjes DJ, Sobel BE, Budd RC: Morphological and cytochemical determination of cell death by apoptosis. Histochem Cell Biol 2008;129:33-43.

7 Walzl A, Unger C, Kramer N, Unterleuthner D, Scherzer M, Hengstschlager M, Schwanzer-Pfeiffer D, Dolznig H: The Resazurin Reduction Assay Can Distinguish Cytotoxic from Cytostatic Compounds in Spheroid Screening Assays. J Biomol Screen 2014;19:1047-1059.

-8 Li P, Nijhawan D, Budihardjo I, Srinivasula SM, Ahmad M, Alnemri ES, Wang X: Cytochrome c and dATP-dependent formation of Apaf-1/caspase-9 complex initiates an apoptotic protease cascade. Cell 1997;91:479-489.

-9 Butterick TA, Duffy CM, Lee RE, Billington CJ, Kotz CM, Nixon JP: Use of a caspase multiplexing assay to determine apoptosis in a hypothalamic cell model. J Vis Exp 2014;10.3791/51305

10 Hengartner MO: The biochemistry of apoptosis. Nature 2000;407:770-776.

11 Niles AL, Moravec RA, Riss TL: In vitro viability and cytotoxicity testing and same-well multi-parametric combinations for high throughput screening. Curr Chem Genomics 2009;3:33-41.

12 Andrade R, Crisol L, Prado R, Boyano MD, Arluzea J, Arechaga J: Plasma membrane and nuclear envelope integrity during the blebbing stage of apoptosis: a time-lapse study. Biol Cell 2009;102:25-35.

13 Shimizu T, Maeno E, Okada Y: Prerequisite role of persistent cell shrinkage in apoptosis of human epithelial cells. Sheng Li Xue Bao 2007;59:512-516.

$>14$ Somasekharan SP, Koc M, Morizot A, Micheau O, Sorensen PH, Gaide O, Andera L, Martinou JC: TRAIL promotes membrane blebbing, detachment and migration of cells displaying a dysfunctional intrinsic pathway of apoptosis. Apoptosis 2013;18:324-336.

15 Nagata S: Apoptotic DNA fragmentation. Exp Cell Res 2000;256:12-18.

16 Nagata S, Nagase H, Kawane K, Mukae N, Fukuyama H: Degradation of chromosomal DNA during apoptosis. Cell Death Differ 2003;10:108-116.

-17 Stanulla M, Wang J, Chervinsky DS, Thandla S, Aplan PD: DNA cleavage within the MLL breakpoint cluster region is a specific event which occurs as part of higher-order chromatin fragmentation during the initial stages of apoptosis. Mol Cell Biol 1997;17:4070-4079.

18 Chan FK, Moriwaki K, De Rosa MJ: Detection of necrosis by release of lactate dehydrogenase activity. Methods Mol Biol 2013;979:65-70.

19 Leventis PA, Grinstein S: The distribution and function of phosphatidylserine in cellular membranes. Annu Rev Biophys 2010;39:407-427.

20 Borra RC, Lotufo MA, Gagioti SM, Barros Fde M, Andrade PM: A simple method to measure cell viability in proliferation and cytotoxicity assays. Braz Oral Res 2009;23:255-262.

21 Riss TL, Moravec RA, Niles AL, Duellman S, Benink HA, Worzella TJ, Minor L: Cell Viability Assays; in (Sittampalam GS, Coussens NP, Nelson H, Arkin M, Auld D, Austin C, Bejcek B, Glicksman M, Inglese J, Iversen PW, Li Z, McGee J, McManus O, Minor L, Napper A, Peltier JM, Riss T, Trask OJ, Jr., and Weidner J, eds) Assay Guidance Manual. Bethesda (MD), 2004, vol. 10.1590/S1806-83242009000300006 p.^pp.

22 Gaucher S, Jarraya M: Technical note: comparison of the PrestoBlue and LDH release assays with the MTT assay for skin viability assessment. Cell Tissue Bank 2015;16:325-329.

-23 Yin LM, Wei Y, Wang Y, Xu YD, Yang YQ: Long term and standard incubations of WST-1 reagent reflect the same inhibitory trend of cell viability in rat airway smooth muscle cells. Int J Med Sci 2013;10:68-72.

-24 Bradbury DA, Simmons TD, Slater KJ, Crouch SP: Measurement of the ADP:ATP ratio in human leukaemic cell lines can be used as an indicator of cell viability, necrosis and apoptosis. J Immunol Methods 2000;240:79-92.

25 Kiesslich T, Gollmer A, Maisch T, Berneburg M, Plaetzer K: A comprehensive tutorial on in vitro characterization of new photosensitizers for photodynamic antitumor therapy and photodynamic inactivation of microorganisms. Biomed Res Int 2013;2013:840417.

-26 O'Brien J, Wilson I, Orton T, Pognan F: Investigation of the Alamar Blue (resazurin) fluorescent dye for the assessment of mammalian cell cytotoxicity. Eur J Biochem 2000;267:5421-5426.

-27 Rampersad SN: Multiple applications of Alamar Blue as an indicator of metabolic function and cellular health in cell viability bioassays. Sensors (Basel) 2012;12:12347-12360.

28 Zalata AA, Lammertijn N, Christophe A, Comhaire FH: The correlates and alleged biochemical background of the resazurin reduction test in semen. Int J Androl 1998;21:289-294. 


\section{Cellular Physiology Cell Physiol Biochem 2017;41:1011-1019 and Biochemistry Publisned \begin{tabular}{l|l} 
DOI: 10.1159/000460910 & $\begin{array}{l}\text { C } 2017 \text { The Author(s). Published by S. Karger AG, Basel } \\
\text { www.karger.com/cpb }\end{array}$
\end{tabular}}

Helm et al.: Cell Death Screening by Viability Analysis

29 Berlanda J, Kiesslich T, Oberdanner CB, Obermair FJ, Krammer B, Plaetzer K: Characterization of apoptosis induced by photodynamic treatment with hypericin in A431 human epidermoid carcinoma cells. J Environ Pathol Toxicol Oncol 2006;25:173-188.

-30 Plaetzer K, Kiesslich T, Krammer B, Hammerl P: Characterization of the cell death modes and the associated changes in cellular energy supply in response to AlPcS4-PDT. Photochem Photobiol Sci 2002;1:172-177.

31 Kiesslich T, Tortik N, Pichler M, Neureiter D, Plaetzer K: Apoptosis in cancer cells induced by photodynamic treatment - a methodological approach. J Porphyrins Phthalocyanines 2013;17:197-209.

-32 Silva MT: Secondary necrosis: the natural outcome of the complete apoptotic program. FEBS Lett 2010;584:4491-4499.

-33 Han Z, Pantazis P, Lange TS, Wyche JH, Hendrickson EA: The staurosporine analog, Ro-31-8220, induces apoptosis independently of its ability to inhibit protein kinase C. Cell Death Differ 2000;7:521-530.

-34 Wachter J, Neureiter D, Alinger B, Pichler M, Fuereder J, Oberdanner C, Di Fazio P, Ocker M, Berr F, Kiesslich T: Influence of five potential anticancer drugs on wnt pathway and cell survival in human biliary tract cancer cells. Int J Biol Sci 2012;8:15-29.

35 Ma W, Teng Y, Hua H, Hou J, Luo T, Jiang Y: Upregulation of heat shock protein 27 confers resistance to actinomycin D-induced apoptosis in cancer cells. FEBS J 2013;280:4612-4624.

-36 Wang X, Wang J, Lin S, Geng Y, Wang J, Jiang B: Sp1 is involved in H2O2-induced PUMA gene expression and apoptosis in colorectal cancer cells. J Exp Clin Cancer Res 2008;27:44.

-37 Berlanda J, Kiesslich T, Engelhardt V, Krammer B, Plaetzer K: Comparative in vitro study on the characteristics of different photosensitizers employed in PDT. J Photochem Photobiol B 2010;100:173-180.

38 Kiesslich T, Plaetzer K, Oberdanner CB, Berlanda J, Obermair FJ, Krammer B: Differential effects of glucose deprivation on the cellular sensitivity towards photodynamic treatment-based production of reactive oxygen species and apoptosis-induction. FEBS Lett 2005;579:185-190.

-39 Pieslinger A, Plaetzer K, Oberdanner CB, Berlanda J, Mair H, Krammer B, Kiesslich T: Characterization of a simple and homogeneous irradiation device based on light-emitting diodes: A possible lowcost supplement to conventional light sources for photodynamic treatment. Med Laser Application 2006;21:277-283.

40 Galluzzi L, Bravo-San Pedro JM, Vitale I, Aaronson SA, Abrams JM, Adam D, Alnemri ES, Altucci L, Andrews D, Annicchiarico-Petruzzelli M, Baehrecke EH, Bazan NG, Bertrand MJ, Bianchi K, Blagosklonny MV, Blomgren K, Borner C, Bredesen DE, Brenner C, Campanella M, Candi E, Cecconi F, Chan FK, Chandel NS, Cheng EH, et al.: Essential versus accessory aspects of cell death: recommendations of the NCCD 2015. Cell Death Differ 2015;22:58-73.

-41 Vander Heiden MG, Chandel NS, Williamson EK, Schumacker PT, Thompson CB: Bcl-xL regulates the membrane potential and volume homeostasis of mitochondria. Cell 1997;91:627-637.

42 Shimizu S, Eguchi Y, Kamiike W, Waguri S, Uchiyama Y, Matsuda H, Tsujimoto Y: Retardation of chemical hypoxia-induced necrotic cell death by Bcl-2 and ICE inhibitors: possible involvement of common mediators in apoptotic and necrotic signal transductions. Oncogene 1996;12:2045-2050.

43 Alam A, Cohen LY, Aouad S, Sekaly RP: Early activation of caspases during T lymphocyte stimulation results in selective substrate cleavage in nonapoptotic cells. J Exp Med 1999;190:1879-1890.

44 Columbano A: Cell death: current difficulties in discriminating apoptosis from necrosis in the context of pathological processes in vivo. J Cell Biochem 1995;58:181-190.

45 Birge RB, Boeltz S, Kumar S, Carlson J, Wanderley J, Calianese D, Barcinski M, Brekken RA, Huang X, Hutchins JT, Freimark B, Empig C, Mercer J, Schroit AJ, Schett G, Herrmann M: Phosphatidylserine is a global immunosuppressive signal in efferocytosis, infectious disease, and cancer. Cell Death Differ 2016;23:962-978.

46 Gyulkhandanyan AV, Mutlu A, Freedman J, Leytin V: Markers of platelet apoptosis: methodology and applications. J Thromb Thrombolysis 2012;33:397-411.

47 Williamson P, Algarin L, Bateman J, Choe HR, Schlegel RA: Phospholipid asymmetry in human erythrocyte ghosts. J Cell Physiol 1985;123:209-214.

-48 Orlov SN, Model MA, Grygorczyk R: CrossTalk opposing view: The triggering and progression of the cell death machinery can occur without cell volume perturbations. J Physiol 2013;591:6123-6125.

49 Orlov SN, Platonova AA, Hamet P, Grygorczyk R: Cell volume and monovalent ion transporters: their role in cell death machinery triggering and progression. Am J Physiol Cell Physiol 2013;305:C361-372. 